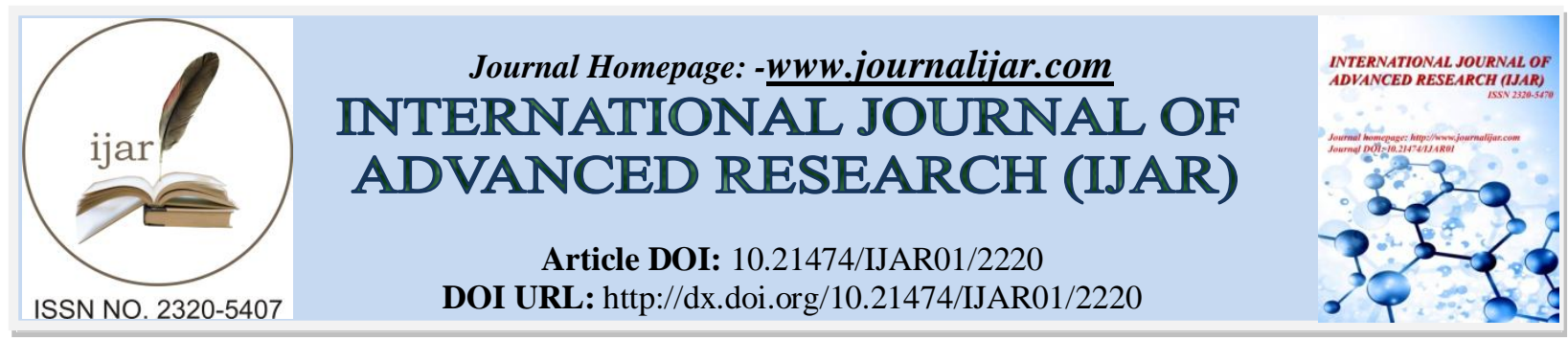

RESEARCH ARTICLE

\title{
SUPERNUMERARY TEETH-REVIEWOFPREVALENCE AND CHARACTERISTICS. PART I.
}

\section{Dr Khaled Khalaf}

PhD, BDS, DAS (Orth.), FDS (Orth) RCS (Eng), FFDRCSI (Orth.), M Orth RCS (Eng), M Orth RCS (Edin), MFDSRCS (Eng), MFDSRCS (Edin), MFDSRCPS (Glasg), FHEA Department of Orthodontics, College of Dentistry, King Faisal University, KSA.

\section{Manuscript Info}

Manuscript History

Received: 28 September 2016

Final Accepted: 30 October 2016

Published: November 2016

Key words:-

supernumerary teeth, hyperdontia, prevalence, review, mesiodens

\section{Abstract}

Supernumerary teeth are defined as an excess in the number of teeth when compared to the normal dental formula. Supernumerary teeth are not an uncommon anomaly with a prevalence range of 0.15 to 3.8 percent. They occur more frequently in the permanent than in the primary dentition and in males more frequently than in females. They can occur almost anywhere in the mouth and may exist unilaterally or bilaterally, but the upper incisor region has been reported as the region most frequently affected by supernumerary teeth. Supernumeraryteeth can be classified according to form or shape, location, time of appearance, extent of eruption and position of supernumerary teeth, and severity of the condition. They present with different severities, but multiple supernumerary teeth are found to be rare especially of cases with more than 2 supernumeraries.

Copy Right, IJAR, 2016,. All rights reserved.

\section{Main Text:-}

Prevalence:-

There have been many case reports concerning supernumerary teeth, but only a few frequency studies have been undertaken (Table 1). ${ }^{1-24}$ Supernumerary teeth are not an uncommon anomaly. They occur more frequently in the permanent than in the primary dentition and in males more frequently than in females. ${ }^{18,20,21,24-31}$ It has been shown from studies on Caucasian children that males were affected approximately twice as often as females in the permanent dentition, ${ }^{18-21,23,32,33}$ whereas the male: female ratio in the Mongoloid populations appeared to be much higher. Saito ${ }^{26}$ and Tayet al. ${ }^{29}$ found this ratio to be 5.5:1 in their studies on Japanese and Hong Kong schoolchildren respectively. In addition, Davis ${ }^{24}$ reported the male: female ratio to be $6.5: 1$ in his study on Hong Kong schoolchildren. Parry and Iyer ${ }^{11}$ found in Indian orthodontic patients a gender prevalence ratio of 1.83:1.

The frequency of supernumerary teeth has been reported to be in the range of 0.15 to 3.8 percentfor various populations, $1,16,17,20,31,34-36$ with higher figures in Hispanic population with a prevalence range between 2 to 2.65 percent $^{37,38}$ and Mongoloid racial groups, where the prevalence was around 3 percent. $^{14,24}$

It appears from the literature that the frequency varies considerably. The differences to a large degree can be attributed to differences in methods of investigation, sampling techniques (particularly differences in the ages of the subjects) and racial derivation of the groups examined. This agrees with Brook ${ }^{39}$ who ascribed a proportion of the differences found in published prevalence studies of dental anomalies of number, form and size to these factors. Certain regions of the dentition have been investigated by some authors, whereas others have investigated only those 
supernumerary teeth that were erupted. Stafne, ${ }^{1}$ Niswander and Sujaku ${ }^{14}$ and Brook ${ }^{20}$ found that only one quarter of permanent supernumerary teeth were erupted. Underestimation of prevalence may occur if studies do not include radiographic examination for unerupted supernumeraries.

\section{Characteristics Of Supernumerary Teeth:- \\ Form or shape:-}

Supernumerary teeth can be classified morphologically as similar to the regular teeth in their shape and size (supplemental) or completely different (rudimentary). ${ }^{35,40}$ Supplemental supernumerary teeth (eumorphic or also referred to as incisiform) defines teeth of normal form including both size and shape. They can be found in both dentitions. In the permanent dentition they are most frequently found as maxillary and mandibular supernumerary lateral incisors, ${ }^{20}$ whereas in the primary dentition they are more likely to arise as supernumerary upper central incisors. Supplemental supernumerary teeth can be found as premolars and molars particularly in African and Asian populations. ${ }^{41}$ In most cases it is difficult to distinguish between the two teeth, the supplemental and the original one. Rudimentary (or dysmorphic) teeth are abnormal in shape and size (usually smaller than normal) and they can be either conical, tuberculate, molariform or odontome in shape.

Conical: This is the most common supernumerary tooth, usually found in the premaxilla and is shaped as described. It has a complete root formation and can be erupted or impacted, normally positioned or inverted. It has little effect on the eruption of the adjacent teeth but may affect their position.

Tuberculate: This is usually barrel-shaped, with an incomplete root. It is also frequently found in the premaxilla palatally and tends to delay the eruption of the adjacent teeth.

Molariform: This has a form similar to a premolar.

Odontome: This is a calcified mixed odontogenic tumour and can present as a compound odontome which appears as multiple miniature teeth, or a complex odontome which appears as an amorphous conglomerate of hard tissue.

Howard ${ }^{42}$ suggested a classification of supernumerary teeth, similar to the above, on the basis of their shape and divided supernumerary teeth into four categories:

- Conical: small, peg-shaped (coniform) teeth usually with normal root (complete root).

-Tuberculate (multicusped): short, barrel-shaped teeth with a normal looking crown, or invaginated, but having a rudimentary root (incomplete root).

- Odontomes, having no regular shape

-Incisiform teeth, which closely resemble adjacent teeth.

DiBiase $^{43}$ and Foster and Taylor ${ }^{44}$ classified supernumerary teeth in the upper central incisor region according to their morphological features as conical or tuberculate in shape. The conical form was the most common.

Parry and Iyer ${ }^{11}$ classified 50 cases with supernumeraries in the maxilla on the basis of their shape and size and their findings were: 38 conical ( 20 small, 17 medium and 1 large) and 12 supplemental ( 2 medium and 10 large).

Out of 100 cases of supernumerary teeth treated at the Dental Hospital in Sheffield, Gardiner ${ }^{10}$ found 23 cases had supplemental teeth, 74 conical or multicuspid and 3 cases had both supplemental and supernumerary teeth. Koch et al. ${ }^{45}$ recorded 56 percent conical, 12 percent tuberculate, 11 percent supplemental and 12 percent other shapes in a study of indications for surgical removal of supernumerary teeth in the premaxilla.

\section{Tooth location:-}

Supernumerary teeth can occur almost anywhere in the mouth and may exist unilaterally or bilaterally.

\section{Left and right side differences:-}

There appears to be no consistent results regarding the occurrence of supernumerary teeth between the left and right sides. In Parry and Iyer'sstudy ${ }^{11}$ it was shown that out of 50 cases of supernumerary teeth found in the maxilla, 33 were with mid-line, 11 on the right side and 6 on the left side.

\section{Jaw difference:-}

The maxilla has been found to be involved more often than the mandible. Ratios reported include: $4: 1,{ }^{46} 5: 1,{ }^{2,47} 8: 1,{ }^{1}$ $8.2: 1^{48-50}$ and $9: 1{ }^{51}$ Primosch $^{35}$ found 90 percent of supernumerary teeth were in the maxilla. Out of 51 cases with 
supernumerary teeth recorded by Parry and Iyer $^{11}$ in 2,000 orthodontic patients, only one case was found in the mandible.

\section{Regional differences:-}

Supernumerary teeth can be classified topographically into three types as follows:

- Mesiodens occurring in the midline region of the premaxilla. These are typically of conical shape and may be found singly or multiply, unilaterally or bilaterally, erupted or impacted and vertical, horizontal or inverted.

- Supernumerary premolars

- Paramolars or distomolars (fourth molars). These are found in the molar region. Paramolars are rudimentary teeth, usually small in size and located buccally or lingually to one of the maxillary molars, or more often in the interproximal space of the second and third molars buccally. Distomolars are usually rudimentary teeth of small size, situated distal to the third molars and these supernumerary teeth rarely delay or impede the eruption of the adjacent teeth.

Different sites within the dental arches have been found to have different relative frequencies of supernumeraries. These are tabulated below.

The upper incisor region has been reported as the region most frequently affected by supernumerary teeth, 1,9, 19-21, 23, $31,36,52$ with the maxillary midline supernumeraries the most common type, followed by the maxillary fourth molars. ${ }^{1}, 17,21,32,36,51,53$ Other supernumerary teeth such as maxillary paramolars, mandibular premolars, maxillary lateral incisors and mandibular fourth molars are seen. Mandibular central incisors and maxillary premolars are occasionally found. Poytonet $\mathrm{al}^{54}$ stated that the most common order of frequency of the occurrence of supernumerary teeth is central incisors, followed by molars, premolars, cuspids and lateral incisors.

\section{Time of appearance:-}

Supernumerary teeth can be classified chronologically ${ }^{40}$ as:

- Predeciduous. This is widely referred to those structures that sometimes could be seen in the gum pads, particularly in the mandibular incisor region, of the newborn child or within the first 30 days of life. Thus they are "inappropriately" called natal and neonatal teeth, although, sometimes they are both called "natal teeth" which is more appropriate. They appear as "horney" structures which are usually shed after the first few weeks of life. Although some authors have pointed out that these teeth may be considered as predeciduous supernumerary teeth, most of these teeth represent prematurely erupted teeth of the deciduous dentition.

- Similar to the permanent teeth. That is, these teeth erupt at the same time of the permanent teeth eruption.

- Post permanent. These teeth erupt noticeably after the permanent teeth have erupted. ${ }^{55-57}$

- Complementary. These supernumerary teeth develop long after the whole permanent dentition have completely erupted.

\section{Extent of eruption and position of supernumerary teeth:-}

Supernumerary teeth can erupt or remain impacted in the jaw. The ratio of impacted to erupted supernumerary teeth has been found to range from 3 to $1^{1,14,20,58}$ to 5 to $1 .^{59}$ Generally, supernumerary teeth in the primary dentition erupt more often than those in the permanent dentition (73\% versus $25 \%)$. ${ }^{1,17,29,37,38,53,54}$ Parry and Iyer ${ }^{11}$ found eruption was confirmed in 35 cases out of 50 cases of supernumerary teeth in 2,000 orthodontic patients. Impaction was seen in 11 cases and 4 cases could not be verified due to a lack of suitable material. This finding does not correspond with the majority of results reported by different authors. The contradiction may logically be explained by the bias in selecting the material for the study. It may have a special interest for comparable studies in orthodontic patient populations only. Unerupted supernumerary teeth are often asymptomatic, discovered as incidental radiographical findings. Hence a complete radiographic screening of the whole oral cavity, particularly in the permanent dentition, is necessary to detect the presence of all impacted supernumerary teeth. ${ }^{54}$

Supernumerary teeth were most commonly found located in a lingual position relative to the dental arch. ${ }^{36,60}$ Nazif and his associates ${ }^{36}$ found that tuberculate, as well as inverted supernumerary teeth were more likely to remain impacted in the jaw. In their sample of 50 patients with impacted supernumerary teeth 20 percent were in an inverted position. Parry and Iyer ${ }^{11}$ found that out of 50 cases with supernumeraries in the maxilla, 41 were properly aligned with the crowns and 9 were inverted. 


\section{Severity:-}

In some studies supernumerary teeth have been found to occur singly in 76-86 percent of all cases, in pairs in 12-23 percent and only less than 1 percent of supernumerary cases have been found to have three or more extra teeth. ${ }^{11,12 \text {, }}$ ${ }^{14,}{ }^{15}$ Stafne, ${ }^{1}$ in his most comprehensive survey, found that only 12 percent of supernumerary teeth patients found had two supernumeraries and 1 percent had three.Grahnen and Lindahl ${ }^{47}$ found in their prevalence study that the supernumerary teeth never exceeded 2 in one individual and only one region was involved in supernumerary teeth in most of the individuals. Others reported that multiple supernumerary teeth occur in approximately 14 percent of the subjects. ${ }^{17,35,36}$ Thus multiple supernumerary teeth are found to be rare especially of cases with more than 2 supernumeraries although cases of multiple supernumeraries have been reported ${ }^{61-67}$ Foley and del Riò ${ }^{68}$ have reported an interesting case of 14 supernumerary teeth with the possibility of a heredity aetiology. So ${ }^{69}$ also reported an unusual case of 14 supernumerary teeth, seven in the maxilla and seven in the mandible, six were symmetrically situated in each jaw in the canine and premolar regions of all quadrants, one between the maxillary right lateral incisor and canine and one between the mandibular right second premolar and first molar.

Table 1:- Prevalence of supernumerary teeth in the permanent dentition (sexes combined).

\begin{tabular}{|c|c|c|c|c|c|}
\hline \multirow[t]{2}{*}{ Author } & \multirow[t]{2}{*}{ Country } & \multirow{2}{*}{$\begin{array}{l}\text { Sample } \\
\text { size }\end{array}$} & \multirow{2}{*}{$\begin{array}{l}\text { Subjects } \\
\text { (Age/years) }\end{array}$} & \multicolumn{2}{|c|}{ Prevalence \% } \\
\hline & & & & Erupted & Total \\
\hline Stafne (1932) & USA & 48,550 & $\begin{array}{l}\text { adults dental hospital } \\
\text { patients }\end{array}$ & & 0.91 \\
\hline MacPhee (1935) & UK (Glasgow) & 4,000 & schoolchildren & 0.3 & \\
\hline Dolder (1937) & Switzerland (Bern) & 10,000 & Schoolchildren (6-15) & 0.3 & \\
\hline $\begin{array}{l}\text { Werther\& Rothenberg } \\
(1939)\end{array}$ & $\overline{\text { USA }}$ & 1,000 & $\begin{array}{l}\text { Schoolchildren } \\
(3-15)\end{array}$ & & 1.6 \\
\hline Tinn (1940) & UK (Yorkshire) & 8,500 & Schoolchildren & 0.3 & \\
\hline Byrd (1943) & Gggenheim & 2,835 & $\begin{array}{l}\text { Dental clinic patients } \\
(4-14)\end{array}$ & & 0.5 \\
\hline Clayton (1956) & USA & 3,557 & $(3-12)$ & & 1.9 \\
\hline Gardiner (1956) & UK (Sheffield) & 1,000 & Schoolchildren & 0.3 & \\
\hline Lind (1959) & Sweden & 1,717 & Schoolchildren & & 3.6 \\
\hline Gardiner (1961) & UK (Sheffield) & 2,250 & $\begin{array}{ll}\begin{array}{l}\text { Dental } \\
\text { patients }\end{array} & \text { hospital } \\
\end{array}$ & & 4.5 \\
\hline Parry \&Iyer (1961) & India & 2,000 & Orthodontic patients & 1.7 & 2.5 \\
\hline Grahnen\&Lindahl (1961) & Sweden (Malmo) & 1,052 & adults dental students & & $1.7-3.1^{*}$ \\
\hline Lacoste et al. (1962) & France & 3,000 & children & & 2.8 \\
\hline $\begin{array}{l}\text { Niswander\&Sujaku } \\
\text { (1963) }\end{array}$ & Japan & 4,150 & $(5-12)$ & & 3.4 \\
\hline $\begin{array}{l}\text { Rosenzweig\&Garbaski } \\
(1965)\end{array}$ & Jerusalem & 28,000 & schoolchildren & 0.1 & \\
\hline Luten (1967) & & 1,558 & $\begin{array}{l}\text { Private } \\
\text { practice }\end{array}$ & & 2 \\
\hline $\begin{array}{l}\text { McKibben \&Brearley } \\
(1971)\end{array}$ & & 1,500 & White children (3-12) & & 1.5 \\
\hline $\begin{array}{l}\text { Egermark-Eriksson } \quad \& \\
\text { Lind (1971) }\end{array}$ & Sweden & 3,608 & $\begin{array}{l}\text { Schoolchildren }(10- \\
16)\end{array}$ & & 1.44 \\
\hline $\begin{array}{l}\text { Thilander\&Myrberg } \\
\text { (1973) }\end{array}$ & Sweden (Umea) & 5,459 & Schoolchildren (13) & & 1.1 \\
\hline Brook (1974) & UK (Buckinghamshire) & 1,115 & $\begin{array}{l}\text { Schoolchildren (11- } \\
\text { 14) }\end{array}$ & & 2.1 \\
\hline Bergstrom (1977) & Sweden & 2,589 & Schoolchildren (8-9) & & 1.5 \\
\hline Bodin et al. (1978) & Sweden & 21,609 & $\begin{array}{l}\text { Patients attending } \\
\text { Dept of Oral Surgery }\end{array}$ & & 1.6 \\
\hline Buenviaje\& Rapp (1984) & USA & 2,439 & $(2-12)$ & & 0.45 \\
\hline Davis (1987) & China (Hong Kong) & 1,093 & Schoolchildren (12) & & 2.7 \\
\hline
\end{tabular}

* 3.1 if the information obtained from the case histories was accepted and 1.7 if was not. 


\section{Conclusions:-}

1. Supernumerary teeth are not uncommon dental anomaly with a prevalence range of 0.15 to 3.8 percent.

2. They can occur almost anywhere in the mouth and may exist unilaterally or bilaterally, but the upper incisor region has been reported as the region most frequently affected by supernumerary teeth.

3. In Caucasian children males were found to be affected approximately twice as often as females in the permanent dentition.

4. Supernumerary teeth can be classified morphologically and topographically.

5. They present with different severities, but multiple supernumerary teeth are found to be rare especially of cases with more than 2 supernumeraries.

\section{References:-}

1. Stafne EC. Supernumerary teeth. Dental Cosmos 1932; 74: 653-659.

2. MacPhee GG. The incidence of erupted supernumerary teeth in consecutive series of 4.000 school children. British Dental Journal 1935; 58: 59-60.

3. Dolder E. Deficient dentition. Dental Record 1937; 57: 142-143.

4. Werther R, Rothenberg F. Anodontia. A review of its etilology with presentation of a case. American Journal of Orthodontics 1939; 25: 61-81.

5. Tinn CA. Exess, deficiency and gemination in the deciduous and permanent dentitions of school children. British Dental Journal 1940; 68: 236-238.

6. Byrd ED. Incidence of supernumerary and congenitally missing teeth. Journal of Dentistry for Children 1943; 10: 84-86.

7. Clayton JM. Congenital dental anomalies occuring in 3557 children. Journal of Dentistry for Children 1956; 23: 206-208.

8. Gardiner JH. A survey of malocclusion and some aetiological factors in 1,000 Sheffield schoolchildren. Dental Practitioner and Dental Record 1956; 6: 187-201.

9. Lind V. Medföddaantalsvariationeripermanentadentitionen, Odontologisk Revy 1959; 10: 176-189.

10. Gardiner JH. Supernumerary teeth. Dental Practitioner and Dental Record 1961; 12: 63-73.

11. Parry RR, Iyer VS. Supernumerary teeth amongst orthodontic patients in India. British Dental Journal 1961; 111: 257-258.

12. Grahnen H, Lindahl B. Supernumerary teeth in the permanent dentition: a frequency study. Odontologisk Revy 1961; 12: 290-294.

13. Lacoste L, Hirsch C, Frank R. Les inclusions dentairessurnumeraires chez 1'enfant. Revue Francaised'Odontostomatologie 1962; 9: 967-983.

14. Niswander JD, Sujaku C. Congenital anomalies of teeth in Japanese children. American Journal of Physical Anthropology 1963; 21: 569-574.

15. Rosenzweig KA, Garbaski O. Numerical aberrations in the permanent teeth of grade school children in Jerusalem. American Journal of Physical Anthropology 1965; 23: 277-284.

16. Luten JR. The prevalence of supernumerary teeth in primary and mixed dentitions. Journal of Dentistry for Children 1967; 34: 346-353.

17. McKibben DR, Brearley LJ. Radiographic determination of the prevalence of selected dental anomalies in children. Journal of International Association of Dentistry for Children 1971; 28 (6): 390-398.

18. Egermark-Eriksson I, Lind V. Congenital numerical variation in the permanent dentition: The sex distribution of hypodontia and hyperdontia. Odontologisk Revy 1971; 22: 309-315.

19. Thilander B, Myrberg N. The prevalence of malocclusion in Swedish schoolchildren. Scandinavian Journal of Dental Research 1973; 81: 12-21.

20. Brook AH. Dental anomalies of number, form and size: Their prevalence in British schoolchildren. Journal of the International Association of Dentistry for Children 1974; 5: 37-53.

21. Bergstrom K. An orthopantomographic study of hypodontia, supernumeraries and other anomalies in school children between the ages of 8-9 years: an epidemiological study. Swedish Dental Journal 1977; 1: 145-157.

22. Bodin I, Julin P, Thomsson M. Hyperodontia I. Frequency and distribution of supernumerary teeth among 21,609 patients. Dentomaxillofacial Radiology 1978; 7: 15-17.

23. Buenviaje TM, Rapp R. Dental anomalies in children: a clinical and radiographic survey. Journal of Dentistry for Children 1984; 51 (1): 42-46.

24. Davis PJ. Hypodontia and hyperdontia of permanent teeth in Hong Kong schoolchildren. Community Dentistry and Oral Epidemiology 1987; 15: 218-220. 
25. Lind V. Medföddaantalsvariationeripermanentadentitionen. Odontologisk Revy 1959; 10: 176-189.

26. Saito T. A genetic study on the degenerative anomalies of deciduous teeth. Japanese Journal of Human Genetics 1959; 4: 27-30.

27. Taylor GS. Characteristics of supernumerary teeth in the primary and permanent dentition. Dent Pract Dent Rec 1972;22(5):203-208.

28. Brook AH. A unifying aetiological explanation for anomalies of human tooth number and size. Archives of Oral Biology 1984; 29: 373-378.

29. Tay F, Pang A, Yuen S. Unerupted maxillary anterior supernumerary teeth: report of 204 cases. Journal of Dentistry for Children 1984; 51: 289-294.

30. Mitchell L. Supernumerary teeth. Dent Update. 1989;16(2):65-69.

31. Rajab LD, Hamdan MA. Supernumerary teeth: review of the literature and a survey of 152 cases. Int J Paediatr Dent 2002;12(4):244-54.

32. Shah RM, Boyd MA, Vakil TF. Studies of permanent tooth anomalies in 7,886 Canadian individuals. Journal of the Canadian Dental Association 1978; 44: 265-276.

33. Locht S. Panoramic radiographic examination of 704 Danish children age 9-10 years. Community Dentistry and Oral Epidemiology 1980; 8: 375-380.

34. Brabant $\mathrm{H}$. Comparison of the characteristics and anomalies of the deciduous and the permanent dentition. Journal of Dental Research 1967; 49: 897-902.

35. Primosch RE. Anterior supernumerary teeth-assessment and surgical intervention in children, Paediatric Dentistry 1981; 3: 204-215.

36. Nazif MM, Ruffalo RC, Zullo T. Impacted supernumerary teeth: a survey of 50 cases. Journal of the American Dental Association 1983; 106: 201-204.

37. Kaler LC. The incidence of mesiodens in children of Hispanic descent. Journal of Pedodontics 1986; 10: 164168.

38. Kaler LC. Prevalence of mesiodens in a pediatric Hispanic population. Journal of Dentistry for Children 1988; 55: 137-138.

39. Brook AH. Variables and criteria in prevalence studies of dental anomalies of number, form and size. Community Dentistry and Oral Epidemiology 1975; 3: 288-293.

40. Grimanis GA, Kyriakides AT, Spyropoulos ND. A survey on supernumerary molars. Quintessence International 1991; 22: 989-995.

41. Foster TD. A textbook of orthodontics. Oxford, Blackwell Scientific Publications 1982; pp. 145-149.

42. Howard RD. The unerupted incisor, a study of the postoperative eruptive history of incisors delayed in their eruption by supernumerary teeth. Dental Practitioner and Dental Record 1967; 17: 332-341.

43. DiBiase DD. Midline supernumerary and eruption of the maxillary central incisor. Dental Practitioner and Dental Record 1969; 20 (1): 35-40.

44. Foster TD, Taylor GS. Characteristics of supernumerary teeth in the upper central incisor region. Dental Practitioner and Dental Record 1969; 20: 8-12.

45. Koch H, Schwartz O, Klausen B. Indications for surgical removal of supernumerary teeth in the premaxilla, International Journal of Oral and Maxillofacial Surgery 1986; 15 (3): 273-281.

46. Fleury JE, Deboets D, Assad C et al. Dents surnumeraires. Revue de Stomatologieet de ChirurgieMaxillofaciale 1984; 85 (2): 142-150. (in French).

47. Grahnen H, Lindahl B. Supernumerary teeth in the permanent dentition: a frequency study. Odontologisk Revy, 1961; 12: 290-294.

48. Schulze C. Incidence of supernumerary teeth. Stoma, 1960; 13: 128-140.

49. Açikgöz A, Açikgöz G, Tunga U, Otan F. Characteristics and prevalence of non-syndrome multiple supernumerary teeth: a retrospective study. DentomaxillofacRadiol 2006; 35(3):185-190.

50. Hall A, Onn A. The development of supernumerary teeth in the mandible in cases with a history of supernumeraries in the pre-maxillary region. J Orthod 2006;33(4):250-255.

51. Shafer WG, Hine MK, Levy BM. A textbook of oral pathology, Fourth ed., Philadelphia: W. B. Saunders Company 1983; pp. 47-50.

52. Anthonappa RP, Omer RS, King NM. Characteristics of 283 supernumerary teeth in southern Chinese children. Oral Surg Oral Med Oral Pathol Oral RadiolEndod 2008;105(6):e48-54.

53. Humerfelt D, Hurlen B, Humerfelt S. Hyperdontia in children below four years of age: A radiographic study. Journal of Dentistry for Children, 1985; 52: 121-124.

54. Poyton GH, Morgan GA, Crouch SA. Recurring supernumerary mandibular premolars. Report of a case of postmature development. Oral Surgery, Oral Medicine, and Oral Pathology, 1960; 13: 964-966. 
55. Marre JM. Supernumerary teeth. Journal of the American Dental Association 1940; 27: 212-214.

56. Oehlers FAC. Postpermanent premolars. British Dental Journal 1952; 93: 157-158.

57. Cowan GA. Delayed development of supernumerary premolars. British Dental Journal 1952; 92: 126.

58. Morgan GA. Unusual cases: recurring impacted supplemental mandibular bicuspids. Journal of the Canadian Dental Association 1951; 17: 84-87.

59. Fastlicht S. Supernumerary teeth and malocclusion. American Journal of Orthodontics 1943; 29: 623-637.

60. Zvolanek JW, Spotts TM. Supernumerary mandibular premolars, report of cases. Journal of the American Dental Association 1985; 110: 721-723.

61. Ruhlman DC, Neely AR. Multiple impacted and erupted supernumerary teeth; report of a case. Oral Surgery, Oral Medicine and Oral Pathology 1964; 17: 199-203.

62. Smith JD. Hyperdontia: report of case. Journal of the American Dental Association 1969; 79: 1191-1192.

63. Duffy MT. Multiple impacted supernumerary teeth. Oral Surgery, Oral Medicine and Oral Pathology 1973; 35 (3): 433-434.

64. Yusof WZ, Awang MN. Multiple impacted supernumerary teeth. Oral Surgery, Oral Medicine and Oral Pathology 1990; 70 (1): 126.

65. Crean SJ, Cunningham S, Coonar HS. Multiple supernumeraries: A case report. Dental Update, 1995; 22: $343-$ 345.

66. Öz AA, Baş B, Öz AZ. The Diagnosis and Management of Multiple Supernumerary Teeth Involving Both Jaws. Int J Orthod Milwaukee. 2015;26(3):45-8.

67. Cruz CV, Soares AL, Braga DN, Costa MC. Diagnosis and Surgical Management of Nonsyndromic Nine Supernumerary Teeth and Leong's Tubercle. Case Rep Dent 2016:8641867. doi: 10.1155/2016/8641867. Epub 2016 Mar 15.

68. Foley MF, Del Rió CE. Supernumerary teeth. Report of a case. Oral Surg Oral Med Oral Pathol 1970;30(1):6063.

69. So LLY. Unusual supernumerary teeth. Angle Orthodontist, 1990; 60 (4): 289-292. 